\title{
Facing the Future? David Owen and social democracy in the 1980s and beyond ${ }^{1}$
}

ABSTRACT: David Owen entered the House of Commons as member for Plymouth in 1966. He became a junior minister under Harold Wilson by 1968 and quickly established himself as a leading figure of the Labour right. From 1977 to 1979 he was Britain's youngest post-war Foreign Secretary under James Callaghan. In response to Labour's apparent leftward drift, Owen defected from the party in March 1981 to jointly lead the Social Democratic Party (SDP) alongside William Rodgers, Roy Jenkins and Shirley Williams. From 1983 until the 1987 General Election he was the party's leader, but stood down after being unable to endorse the merger of the SDP and Liberal parties. He re-launched a 'continuing SDP' on the 8 March 1988 which, after failing to build a base of popular support, was disbanded on 3 June 1990. Owen resigned his seat at the 1992 General Election.

This article argues that understanding Owen's political career, and in particular his political thought and its relationship with his role as SDP leader, is important in comprehending the fortunes of the British centre-left in the last two decades of the twentieth-century. It suggests that the task of the British centre-left was defined by Owen and the SDP as a need to create a new synthesis of ideas that could keep the values and attitudes of mind that previous left thinkers had upheld on the political agenda of the 1980s. The outcome was an ideological retreat that demonstrated the difficult conditions in which social democrats were attempting to find intellectual renewal.

Although he was one of the most publicly recognised parliamentarians of postwar Britain, until recently David Owen has received little scholarly attention. The absence of any biographical volume can partly be attributed to the extent of his own autobiographical work, but that does not explain why so little has been written to try and clarify and understand the many fruitful questions that arise from his political career. ${ }^{2}$ One factor has been the unwillingness to regard Owen as a serious 'intellectual' politician. Unlike R.H Tawney, G.D.H Cole, Anthony 
Crosland and other progressive thinkers of the twentieth-century, Owen seemed to be a figure of the British left that had little more than a passing concern for 'ideas'. Attention has tended to focus on his leadership qualities rather than his intellectualism. However, while Owen may not have had the academic connections of previous intellectually-minded left-wing thinkers, he was certainly concerned with ideas. He read widely and dedicated a good deal of time attempting to construct a new ideological base for British social democracy over the course of the 1980s. That is not to say that he was able to offer a comprehensive re-statement of social democratic philosophy. As a party leader he was concerned with formulating concrete policies and winning votes, tasks that occasionally led him to denounce ideology rather than embrace it. Acknowledging this, however, should emphasise the need to study Owen more deeply rather than dismiss him as an insignificant thinker. The tension that existed between his attempt to re-formulate social democracy and pursue these goals is important to understanding the fortunes of the British centre-left in the 1980s and beyond.

Despite the relatively sparse scholarship on Owen, four writers have engaged with his efforts to re-define social democracy in the 1980s: Tudor Jones, Duncan Brack, Matt Beech and Matthew Lakin. ${ }^{3}$ The common theme has been to discuss Owen's ideas in relation to Britain social democratic tradition; engaging heavily with the SDP's pre-history and legacy. Jones' and Brack's earlier analysis chimes with wider declinist narratives of the SDP, arguing that Owen did little to coherently re-define Britain's social democratic tradition in the 1980s. ${ }^{4}$ For Jones, Owenite thinking was not successful in providing a clear ideological re-definition of social democracy. For Brack, Owen represented a substantial departure from the British social democractic tradition due to its 'ditching of old Labour commitments'. ${ }^{5}$ Reacting against the declinist narrative of Owen and the SDP, Beech and Lakin, by contrast, have recently asserted that Owen's ideas provided a model for a post-Thatcher 'renewal' of social democratic politics. Lakin has gone as far as to claim that 'Owen's influence has permeated to all regions of mainstream political ideology in contemporary post-Thatcher politics and has helped social democracy claim legitimacy well on into the twenty first century. ${ }^{\prime} 6$

This article argues that there is a need to reconsider Owen's contribution to British politics and his relationship with preceding and succeeding modes of centre-left thought. Owen and his intellectually-minded followers in the SDP were concerned with creating a new synthesis of ideas that could sustain the goals of social justice and fellowship pursued by social democracy; attempting to ensure that they still had a significant place on the political agenda. To argue that in doing so Owen laid the foundations for a 'renewal' of social democracy to make it applicable to the 1980s and beyond ignores the ideological sacrifices that the Owenite project made in attempting to pursue this agenda. The 
synthesising qualities of Owenism were indicative of the difficult terrain that was requiring the British centre-left to radically re-think its policies, ideology and image.

\section{From Labour to the SDP, 1966-1983}

One of the myths of the SDP's history is that it was a party tied to the intellectual legacy of Anthony Crosland. Such an argument would make the false assumption that the party collectively agreed upon its ideological direction and that this direction stayed consistent throughout its life. ${ }^{7}$ Nonetheless, it is true that Crosland's influence is detectable in early statements of SDP ideology. Emerging from the common ideological denominators of the Gang of Four, early SDP policy tended to echo the Croslandite ideas that had been hegemonic within the Parliamentary Labour Party since the early 1960s. The main thrust of Harold Wilson's policy programmes - the commitment to an expanding welfare state sustained by full employment and a Keynesian economic strategy - was clearly present in early SDP policy statements, which to some observers was symptomatic of an ideological continuity. ${ }^{8}$ Inigo Bing, a member of an SDP think tank, wrote in 1984 that philosophical thinking in the party, 'seems only to be looking backwards towards Tawney and Crosland', while Liberal Jeremy Josephs wrote 'the new party had come into being more from a crisis in the Labour Party than from any commitment to the newly-discovered principles of social democracy.' David Sainsbury, who provided much of the SDP's financial resources, reflected in a confessional statement: 'the people at the top in a sense were still harking back, and I include myself in that, to an earlier period of the Labour Party, which went back to the best of the 1960s' policies. ${ }^{10}$ One of those 'people at the top', William Rodgers, struck a similar tone in a passage of his memoirs:

We were, I suppose, still 1960s' Labour revisionists. I was now highly critical of the trade unions, but not ready to turn my back on them; I believed in an incomes policy, developed in a straight line from the policies of the two governments in which I had served; and I was an unrepentant egalitarian, taking for granted that only a high level of public expenditure (and therefore taxation) was consistent with achieving the social objectives about which I cared. ${ }^{11}$

Sainsbury and Rodgers were not, however, accurately describing the intellectual trajectory of David Owen, who significantly revised his thinking in the wake of the SDP split and attempted to attach the party to a different ideological base during his tenure as leader.

Owen's willingness to stretch beyond the conventions of Britain's social democratic tradition can partly be explained by an exploration of his political biography. In his political youth Owen had not strongly identified with the 
cultural identity of the Labour Party. As a university student he had been impressed by the oratory of Hugh Gaitskell and the intellectual exuberance of Crosland's The Future of Socialism (1956), but his Labour membership was nominal in his late twenties. Indeed as he entered the selection process for parliamentary candidature his knowledge of Labour politics was so limited that he paraphrased from a copy of the New Statesman at his initial interview. ${ }^{12}$ Nor was the young Owen a figure who was deferential to the party's leadership. When he became a Labour MP for Plymouth in 1966 he was far from a Wilson loyalist. As a member of the 'Snakes and Alligators' group he criticised the delay over devaluation and co-authored a Socialist Commentary pamphlet that challenged the government's incomes policy. ${ }^{13}$ Owen even believed that he was offered his first ministerial position by Harold Wilson in 1968 precisely because he was 'potentially dangerous on the back benches'. ${ }^{14}$ This detachment from Labourism goes some way towards explaining his willingness, once he defected, to abandon the programmatic themes associated with the intellectuals he was considered closest to within Labour.

Despite this, Owen's openness to new ideas took time to evolve. His route to defecting from Labour was long and, as his autobiography details, extremely painful. ${ }^{15}$ When he first considered the possibility of a new party, Owen chose to define it as a possible tool for reviving the principles that Labour had abandoned:

If the Labour Party abandons its democratic and internationalist principles, the argument may grow for a new democratic socialist party to establish itself as a party of conscience and reform committed to those principles. ${ }^{16}$

Published before the SDP split, Face The Future (Jan. 1981) was, in Owen's own words, 'neither revisionist nor traditionalist' and expressed only a halfformed ideological shift. ${ }^{17}$ Sympathy with the socialist 'ends' of equality, fellowship and freedom remained in tact in a Croslandite manner to the extent that Labour MP and committed Croslandite Philip Whitehead was prepared to write that the book was 'written by a socialist, for a socialist' ${ }^{18}$ But the fact that it was written for socialists is perhaps why the break with the past was not more substantive. Conceived at a time when Owen was attempting to rebuild a new consensus within the right of the Labour Party rather than outside it, Owen may have been reluctant to depart more sharply from the Croslandite formula. The abrupt removal of the word 'socialism' from the paperback edition, released in the wake of the SDP split, gave a more accurate indication of Owen's rethinking. ${ }^{19}$ Even in its original form the book was informed by ideas that would never have sat easily within the boundaries of a 1960s or 1970s Labour Party policy document. ${ }^{20}$ While out of office during Heath's premiership Owen became chairman of an American computer consultancy firm, an experience which taught him about 'the management and ethos of the private sector' and encouraged him 'to challenge the Tony Crosland revisionist economic stance 
which had paid scant attention to making markets work efficiently. ${ }^{21}$ Face The Future began to bear the fruit of this experience by attacking the corporatism and top-down reform that had marked Labour's programmes since 1945 and emphasising the need to foster 'the commercial and competitive imperatives on which our prosperity depends'. ${ }^{2}$

Although the SDP-Liberal Alliance managed to secure 25 per cent of the popular vote in the 1983 General Election, this translated to just 6 SDP seats in the House of Commons. Roy Jenkins quickly passed on the leadership of the party to Owen, whose own diagnosis of the election was that the party's policies had not appealed to a sufficiently large constituency of voters. Only by converting Conservative voters, Owen believed, could the Alliance break the mould of British politics at the next election: 'the SDP would attempt to throw off the centrist 'splitting the difference' image with which we had been landed...It was worth a gamble.' 23 The route to doing so, in Owen's mind, was to attach the SDP to a new ideological base. ${ }^{24}$

\section{Looking Back: The Owen Synthesis and Croslandite Social Democracy}

From the late 1950s many of the ideological characteristics that were hegemonic in the Parliamentary Labour Party resembled the ideas present in Anthony Crosland's revisionist work The Future of Socialism (1956). Indeed Owen has admitted that Crosland's book 'had a profound impact upon me and many of my generation. ${ }^{25}$ Within it Crosland put the principle of equality at the very centre of his definition of socialism and demonstrated a desire to eradicate Britain's social hierarchy. He argued that extensive public ownership was unnecessary to pursue this equality; the mixed economy managed by Keynesian policies, he believed, could grow sufficiently to make allowances for substantive increases in public expenditure that would provide the means for achieving socialist ends. The Future of Socialism was notable for its willingness to look beyond conceiving social justice in terms of improving material conditions; enhancing happiness meant much more than securing the alleviation of poverty.

It would be a mistake to see the entire breadth of Crosland's thinking as the benchmark against which future expressions of social democratic thinking should be judged for authenticity. Nonetheless, the way in which his socialism connected equality to other desirable qualities like freedom and fellowship, but retained egalitarianism as its highest ranking priority, certainly characterised the core of the British social democratic tradition for over two decades. Even senior SDP intellectuals like David Marquand seemed to cling to this as the definition of social democracy well into the $1980 \mathrm{~s}^{26}$ 
Over the course of the 1970s Crosland's thinking began to be questioned. His plans had rested on the assumption that there would be economic growth and that, through Keynesian measures, government could ensure this growth. In the difficult economic conditions of the 1970s such assumptions no longer seemed secure and social democrats, particularly after Crosland's death in 1977, began to seek a new framework of economic thinking to sustain their ideological beliefs. Increasingly, David Owen became the most high-profile figure in the efforts to fill the ideological vacuum that had appeared on the centre-left. Crosland had argued in 1956 that he had merely revised the means through which socialism could be achieved; the socialist ends remained the same. The question to apply to Owen is whether, in revising Croslandite revisionism, the ends as well as the means had become transformed.

Before pursuing an answer we can firmly reject the arguments made by some contemporary Labour and Liberal members that the Owen of the late 1980s sympathised with the ethical assumptions of the New Right. Thatcher's reverence for Victorian values, and the anti-welfarist attitudes that accompanied it, were never a component of Owen's revisionism. ${ }^{27}$ In a revealing passage from his memoirs Owen wrote that Mrs Thatcher: 'has never been able to understand the non-achievers or how society, whose existence she denies, has a public responsibility to help shoulder some of their burdens. ${ }^{28}$ A strong commitment to social justice was present in his writings throughout the 1980s; an early SDP speech in Salford Owen declared, 'We must not shy away from talking about values, love, charity, altruism'. ${ }^{29}$ The key question to ask of Owen's post-Labour trajectory is whether this morality was attached to a fullblooded social democratic belief.

Despite his outspoken desire to make the SDP break with the Labourite 'consensus' of the 1950s and 1960s, Owen retained some sympathy with many of the ideological characteristics of previous Labour intellectuals like Evan Durbin and Tony Crosland. Some commitment to equality, the lynchpin of Crosland's social democracy, was upheld by Owen throughout his tenure in the SDP. Its character, however, changed over time. Face The Future (1981) stated that the central aim of any government should be equality; dedicating 100 pages to explain that equality was a higher moral goal than liberty for its own sake. ${ }^{30}$ In his 1984 book A Future That Will Work Owen continued to announce his dedication to creating 'an open, classless and more equal society', but egalitarianism was a much less dominant feature. By this time Owen's definition of equality was strongly aligned with the conception of social justice developed by American liberal philosopher John Rawls. ${ }^{31}$ A just society, Owen wrote, was one, 'in which its worst-off members are as well off as they can be. In such a society the rich might well get richer as long as the prospects of the poor are raised as a consequence.' Under this definition, Owen admitted, 'there 
is no pretence that all will, or can be equally rewarded'. ${ }^{32}$ Understanding the nature of Owen's accommodation with Rawls is central to the task of untangling his relationship with the British social democratic tradition.

In his final book Socialism Now (1972) Crosland had also, at least partially, endorsed Rawls. That did not mean, however, that he shared the same vision of equality with the Owen of the mid-1980s. ${ }^{33}$ Rawls' definition of social justice lay in the spectrum between equality of opportunity and equality of outcome and invited politicians to use empirical judgements to determine their own place on this spectrum. Owen and Crosland chose substantially different locations.

Crosland's revisionism had been marked by his commitment to preserving significant inequalities of income in order to create the incentives necessary for the pursuit of economic prosperity. In The Future of Socialism Crosland was reluctant, in an echo of Rawls, to define socialism in terms of the 'overall vertical equality of incomes' ${ }^{34}$ Crosland also made it clear, however, that equality of opportunity, in itself, did not make up a social democratic commitment; the fruits of the prosperity that these incentives might produce had to be redistributed:

From a socialist point of view, the limited goal of equality of opportunity is not enough, it needs to be combined with measures, above all in education, to equalise the distribution of rewards and privileges so as to diminish the injustices of large inequalities and the collective discontent which comes from great disparities of wealth. ${ }^{35}$

It is not the purpose of this article to debate at length the compatibility of Rawslian principles with social democractic objectives, partly because Owen did not absorb Rawls on a wholesale basis: only Rawls' anti-utilitarianism and definition of social justice caught Owen's interest. It is important, however, to acknowledge that Rawls, despite arguing that equality and liberty were mutually reinforcing, did not endorse the idea that all egalitarian measures were conductive to a just society. 'Undeserved' inequalities - whether the result of accidents of birth or geographical location - were not to be automatically subject to redress. Rawls merely believed that people could only benefit from these inequalities if the condition of the worst-off was improved as a consequence. Therefore Rawls, unlike the orthodox socialist view, did not see redress as a matter of principle in itself. As a result of his emphasis on equal liberty, as one SDP intellectual pointed out, Rawls essentially implied that any redress could only be just if taking place in the context of economic growth; the rich should not be automatically deprived of their arbitrary economic status at the expense of the worst-off. ${ }^{36}$ It must also be noted that his conception of justice failed to deal with the inequalities of those people who were not at the very bottom of the social ladder. Owen's accommodation with these aspects of 
Rawls' thinking seemed to mark a departure from some aspects of Crosland's social democratic commitment. ${ }^{37}$

In a sense Owen gravitated towards Rawls' emphasis upon equal rights because it provided an alternative to thinking about the distribution of resources in material terms. Maximum justice and equal rights, Owen wrote, were 'more inspiring than advocating equality of income, a goal which few believe in and even fewer are prepared to work for. ${ }^{38}$ Indeed, placing faith in Rawls allowed Owen to pursue an agenda of social justice that was compatible with a value upon enterprise and competition. His concept of the social market - an economic policy that could 'grapple simultaneously with the values inspired by a competitive market economy and the values to be fostered in a society determined to reduce social deprivation' - must therefore be understood as a byproduct of his Rawlsian sympathies. ${ }^{39}$

Although the social market was not defined with much precision in Owen's writings, expressions of the term that were rooted in Rawlsian language seemed to embody a retreat from a full-blooded social democratic political economy. Non-SDP social democrats like Bernard Crick argued in this period that in order to be social democratic in form, values of liberty and fraternity had to be linked to egalitarianism. In other words, positive liberties - the allocation of resources allowing individuals to pursue their potential - had to have a strong place within any social democratic conception of freedom. ${ }^{40}$ It can certainly be questioned whether Owen's vision, as it emerged from 1983, pursued this link with much enthusiasm. Owen did not rule out redistributive policies that could promote positive liberties but, as an outcome of its Rawlsian logic, the social market became substantially less concerned with redistribution in this respect as the decade wore on. As Robert Behrens wrote in 1989, the social market constituted an effort to shift the emphasis of social democracy from a 'strategy of distribution which was dependent on economic growth, to a strategy of production which promoted economic growth'. ${ }^{41}$ Owen was much more concerned with answering the question, 'how can we eliminate poverty and promote greater equality without stifling enterprise or imposing bureaucracy from the centre? ${ }^{42}$ In providing an answer Owen promoted anti-bureaucratic and pro-enterprise themes that were much more wedded to promoting negative liberties; the absence of restraint.

When promoting these freedoms Owen's altruism often sidelined egalitarian goals. Equality of outcome, Owen believed, could be the enemy of freedom as much as its facilitator. In A Future That Will Work he contended that 'a compassionate and caring society would not always propose the same policies as one aiming at achieving an egalitarian society. ${ }^{43}$ It was this logic that inspired the SDP's 'Basic Benefit' scheme, a policy designed to help only the worst-off and enhance incentives for lower-income workers: 'In Britain reliance on the state has gone too far, and the result has been a loss of drive and dynamism and a playing-down of the importance of market forces as 
the progenitor of change and progress.' ${ }^{4}$ While in Socialism Now (1972) Crosland was still calling for 'a stronger determination to achieve egalitarian priorities', and continued to be insistent that it was inequalities, not equalities, that had to be subjected to scrutiny, a decade later Owen was increasingly disposed to see some forms of equality as destructive rather than constructive, and would often substitute a commitment to 'fairness' for more explicit egalitarian promises. ${ }^{45}$

This shifting conception of desirable equality came alongside the evolution of Owen's attitude towards the market. In Face The Future (1981) Owen had held some sympathy with those socialists who were disillusioned by 'the rapacious nature of a growth-orientated society with its emphasis on materialism, competition and money.' ${ }^{\prime 6}$ By 1984 this caution had subsided and a market economy was regarded as the most suitable means of achieving economic growth.

It was this enthusiasm for the market that distinguished Owen most sharply from other social democratic thinkers of the period. ${ }^{47}$ Raymond Plant, the social democratic thinker and subsequent Labour peer, provides a useful subject for comparison. Although he accepted a role for markets in a socialist economy, Plant 'aimed to weaken the idea that markets should be the dominant mode of allocation' and wished to reinforce the idea that 'egalitarian socialism is a threat to the values which markets represent. ${ }^{48}$ The 'social' component of Owen's social market of course suggested some sympathy with Plant's view that market outcomes were often unjust, but taken as a whole the concept raised little contest with the idea that the values the market incorporated were destructive. ${ }^{49}$ Earlier talk of 'persuading and cajoling' the better-off to make sacrifices for the poorest disappeared and was replaced with the idea that material abundance could enhance the individual's willingness to contribute to the 'common good'. ${ }^{50}$ David Marquand has drawn attention to the fact that Owen spoke to the entrepreneurial 'New Men' of the 1980s who appeared to be heralding a new age of enterprise. ${ }^{51}$ Plant in fact cited the public debut of the Owenite social market - made in Owen's speech at the SDP conference in Salford (1983) - as an example of the growing influence of anti-egalitarian ideas. ${ }^{52}$ How the social democratic value of fellowship fitted within an economic policy that had little desire to temper the competitive, acquisitive impulses of the market economy is certainly difficult to determine. Even in a generally favourable review of A Future That Will Work, The Economist argued that the book could not be regarded as a philosophical restatement of social democracy precisely because Owen failed to reconcile the goals of compassion and competition. ${ }^{53}$ 
In relation to the Croslandite consensus of the 1960s and 1970s, then, Owen was much more concerned with pursuing enhancements in liberty than he was with pursuing further redistributions of wealth. Indeed in his accommodation with Rawls he essentially defined the renewal of social democracy in terms of the renewal of liberalism, in many ways looking to a more individualist society: 'Ours was a desire for radical change; the wish for strong, creative, individualist, irreverent society, a society whose government and institutions supported the diversity and variety of individuals and communities rather than stifling them in a centralized bureaucracy. ${ }^{54}$ Social democracy, however, as SDP parliamentary candidate Stephen Mennell wrote in an early Tawney Society paper, was a collectivist rather than individualist doctrine. ${ }^{55}$ Crosland's libertarian streak led him to endorse greater private freedom and cultural diversity but he nonetheless remained a strident collectivist throughout his life. He defended inequalities of outcome only on the basis that they could, through the growth they encouraged, be conductive to a collective accumulation of capital. ${ }^{56}$ For Owen, the criteria for justifying inequality seemed to be less aligned with this collectivist analysis. Tax reductions to help release the talents of the middle class, the privatisation of numerous industries, and his desire to curb an 'opportunity-denying' state all pointed to a more individualist conception of a just society.

In his later writings G.D.H Cole seemed unable to reach beyond his wartime accommodation with a 'liberal socialism' that upheld the mixed economy as a stepping stone to socialism; opposing the 1950s revisionism that saw it as compatible with socialist ends.$^{57}$ In turn, the leading intellectual of this revisionism, Crosland, appeared unwilling to stretch his synthesis much further by the early 1970s, jostling uncomfortably with the idea that his egalitarianism was stifling individual excellence. Owen, in his 'revision of revisionism', was not encumbered by either Labourism or the ideological baggage that came with it. He was determined that the most skilled and the most ambitious would not be held back by any dogmatic commitments and wished to release the inventive talents of the expanding middle-class by reversing the 'crippling levels of personal taxation in the 1960s and 1970s'. ${ }^{58}$

The reaction of the other members of the 'Gang of Four' to Owen's ideological transition was indicative of Owen's departure from the Croslandite model of social democracy. Roy Jenkins' writing in the 1970s was very much against the grain of Owen's post-1983 ideas, criticising selective benefit schemes that could be 'in grave danger of helping the very poor at the expense of the not quite so poor' and making the case for substantive redistribution of wealth even in the context of low economic growth. ${ }^{59}$ Despite the fact that he failed to offer a full account of his views in the 1980s, many of these themes emerged in speeches 
and short articles during his tenure as SDP leader. ${ }^{60}$ By 1984 he became sceptical of what he called Owen's 'junior Thatcherite' approach, stating in an interview, 'He's much more pro-Thatcher than I am. He's more Conservative in economic matters and perhaps foreign affairs. ${ }^{61}$ William Rodgers similarly claimed that, '[Owen] began to turn away from the social democratic, 'conscience and reform' centre-left'. ${ }^{62}$

The broader intellectual environment of the SDP raised similar reservations. Although some early correspondence of the SDP's think tanks (the Tawney Society and the Political Philosophy Forum) included Owen's name, the groups, on the whole, largely operated without his direct input. ${ }^{63}$ In many respects Owen glossed over the concerns that the Tawney Society and PPF raised regarding the 'new' social democracy that Owenism represented; how to reconcile decentralisation with equality and how to pair up enthusiasm for the free market with concern for fellowship. Rawls was discussed, but there was only a limited accommodation with his ideas. Similarly, worries about the unfettered market were common and many were worried about the SDP's apparent fixation with arresting economic decline: 'David Owen [is] very 'macho' on profit; did he have to take it so far?' ${ }^{64}$

\section{Explaining Owen's transition}

The Owenite synthesis of the mid-to-late 1980s, then, was not social democratic in the same sense as Labour revisionists of the 1950s and 1960s would have recognised the term. Marquand has put it simply, 'the SDP was never a Croslandite party and Crosland would never have felt at home in it. ${ }^{65}$ The egalitarian impetus behind Owen's thinking from around 1984 was much more weighted towards equality of opportunity than equality of outcome and New Liberalism seemed to be just a much a part of Owen's philosophy as the social democratic values of Tawney or Crosland. Incentive, enterprise and competition loomed much bigger in his vision than fellowship and Croslandite egalitarianism, although the latter values had certainly not disappeared.

The processes of thought that led Owen towards his synthesis, however, had many of the same characteristics as those of his social democratic predecessors, particularly Crosland and Durbin. One of the distinctive features of the socialist revisionism of the late 1940s and 1950s was a willingness to recognise that constructive human attributes were present on both sides of the political spectrum. ${ }^{66}$ It was a belief very much present in Owen's thinking as he attempted to incorporate qualities of human character associated with the right personal ambition and enterprise - into a compassionate centre-left political agenda. But while Crosland and Durbin were concerned with 'channelling' these 'lesser' qualities of mind, Owen was prepared positively to endorse them. In an early SDP publication Owen declared a desire to create an 'enabling society' in which, 'effort is respected no less than altruism is revered and 
encouraged. ${ }^{67}$ 'Effort', couched in terms of entrepreneurialism, ranked equally with what had conventionally been social democracy's 'higher' values of fraternity and altruism. It was a belief that came alongside the rejection of the search for reform through state action more than individual behaviour. ${ }^{68}$ In sharing the revisionist impulse towards synthesis, and taking it a stage further, it can be argued that he had diluted the strength of his commitments to the core value of Crosland's belief system: equality.

Owen's synthesis, and his ideological trajectory, has to be understood in the context of his role as leader of the SDP. One of the motivating factors for Crosland and Durbin's synthesising character had been electoral realism. As Jeremy Nuttall has written, they believed that 'to be in politics and not to seek to win [elections] was a betrayal, an indication of incompetence and emotional self-indulgence. ${ }^{69}$ Owen agreed with this reasoning wholeheartedly. But while Crosland and Durbin merely aimed to make their party appear less aligned with working-class interests in their efforts to secure the success of the Labour Party, Owen's task as SDP leader seemed to require a much more radical shift.

In 1974 Crosland conceded that 'Good \& Socialist policies [are] not electorally popular ${ }^{70}$. He was not willing, however, to sacrifice redistributive policies to try and please the middle-classes, often favouring policies that assisted the urban poor at the expense of wealthier suburban population. ${ }^{71}$ A decade later Owen seemed to respond to the apparent decline in the popularity of social democratic ideas in a very different way. Working-class Toryism was something he observed from personal experience: 'I have often put my foot in the door when it was being slammed in my face on a council estate by a dockyard worker saying, 'We're true blue here'" ${ }^{72}$ The middle-class, he acknowledged, formed the largest social grouping in British society, and although they retained a social conscience, they were also anxious to gain material wealth and objected to the intrusion of the state into their lives. Capturing their votes, Owen believed, required a ditching of the SDP's 'Mark II Labour' image. ${ }^{73}$ The social market was Owen's primary tool in this task.

The fact that the social market was conceived by Owen as having utility as a propaganda device partially explains why it was so ideologically ambiguous, and says much about the broader fortunes of social democracy in the 1980s and beyond. ${ }^{74}$ The social market could either mean importing market mechanisms into the delivery of public goods and services, as Keith Joseph had conceived, or it could mean advocating the pursuit of a successful market economy whose 'negative' outcomes should be repaired by the state. Owen, at different times, acknowledged the merits of both conceptions. In A Future That Will Work the emphasis seemed to be on the latter, but by the end of the decade it seemed to have shifted to the former as Owen propagated the creation of an 'internal market' within the NHS. ${ }^{75}$ This changing definition seems to be evidence that the twin tasks of placing social democratic ideas on the political 
agenda and creating an electorally-attractive programme were fighting against one another.

It has already been noted that Owen's embrace of Rawls was a means of abandoning traditional social democracy and embracing the market whilst also maintaining social justice as a key goal of his belief system. It was also, by consequence, part of a determination to distance the SDP from Labour whilst also tapping into some of the popular elements of Thatcherism. It is difficult to understate the acceleration of Owen's revisionism in the wake of the 1983 General Election. Owenism was as much a consequence of electoral realism as it was an organic product of Owen's changing ideology; he read Rawls in search of votes as much as a personal grounding for his beliefs. ${ }^{76} \mathrm{~A}$ similar diagnosis can be made of the way that economic declinism fed into Owen's revisionism. Owen was aware of the popularity of Thatcher's brand of declinism and sought to create his own version by aligning economic decline with the 'political decline' of Britain's Establishment. ${ }^{77}$

Many Liberals who experienced the damaging impact of Owen's opposition to SDP-Liberal merger in 1987 have been critical of his actions, and many struggled to understand his determined stance. ${ }^{78}$ There certainly seemed to be little in the way of an ideological divide. Indeed this article has argued that Owen essentially conceived of his revisionism in terms of reviving social democracy through a renewal of liberalism; there was nothing in the social market that was in serious conflict with Liberal ideology. ${ }^{79}$ The divide was instead a cultural one. Owen disliked what he perceived as the 'small ' 1 ' liberalism' that prevailed in the Liberal Party and its inherent passion for compromise and civility. He opposed merger because he believed it could serve to muddy the political identity of the centre. ${ }^{80}$ Owen's stance on merger offers a key indication as to why Owenism failed to provide a more comprehensive ideological base for the renewal of the centre-left. The desire to attach the SDP to a unique image, for the purposes of electoral gain, was always intrinsically tied to the task of re-thinking. As a result, the ideas that emerged were often required to be ambiguous and ideologically flexible. It is perhaps for this reason that one Liberal described Owen's radicalism as 'a sort of free-floating populism made up of anger against men and measures'. ${ }^{81}$

\section{Facing The Future? Owen and New Labour}

In many ways Owen's attempt to reformulate social democracy in the 1980 s took place in a hostile climate, both intellectually and politically. Within a decade of the SDP's demise, however, social democracy seemed to have experienced resurgence as centre-left parties came to power across Western Europe, including the New Labour project led by Tony Blair. In light of this development, recent studies have attempted to locate David Owen as something of a pre-cursor to Blair's remoulding of Labour's ideological approach. Matt 
Beech has understood Owen as a 'proto-New Labour politician'. ${ }^{82}$ His modernising agenda, Beech argues, provided a template for Blair. Lakin has gone further, aligning Owen with a renewal of British social democracy.

There are certainly programmatic similarities between the late SDP and early New Labour, which Owen himself has identified:

It's pretty obvious there are very substantial chunks of SDP policy - in fact hardly any innovative policy the New Labour espouse - that wasn't advocated by the SDP between 1981 and 1990. I can't think of a single policy that hasn't been espoused by the SDP at one stage. ${ }^{83}$

The architects of New Labour, however, did not have an intellectual engagement with Owenism, indeed some New Labour thinkers like Peter Mandelson were openly critical of Owen's ideas in the mid-1990s. ${ }^{84}$ Any programmatic similarities between Owen's SDP and Blair's New Labour, therefore, were arrived at as a by-product of their similar ideological trajectories rather than an Owenite intellectual legacy. ${ }^{85}$

Owen's revisionism very much evolved in line with a shifting interpretation of economic and social change. Statements of Owen's thinking in the late 1970s had echoes of the transformative intentions of Croslandism and continued to focus on the levelling of Britain's social hierarchy. From 1983, partly as a result of an electoral realism, Owen was increasingly sensitive to meeting the demands of increasingly inter-dependent economy and a more individualist British society.

Blair and New Labour engaged in a similar dialogue with the economic and sociological 'realities' they observed in the post-Thatcher world and the outcome was an echoing of Owen's ideological journey. After some flirtation with a more full-blooded social democratic political economy in the early 1990s, New Labour mirrored Owen's qualified endorsement of the market by the time of the 1997 General Election. ${ }^{86}$ Social policy statements were increasingly redolent of Owen's celebration of a more entrepreneurial culture and shared his emphasis on less universal forms of welfare that had selfimprovement as their underlying themes. ${ }^{87}$

Blair's own personality, image and style also struck an Owenite tone. A comparison of Owen's account of the 1985 SDP conference and Blair's own reminiscence of his actions at Labour's conference nine years later expose some striking similarities in this regard. ${ }^{88}$ Both were men expressed their detachement from the cultural character of Labourism, a distaste for tradition and custom and a strong modernising ethos that could appeal to the aspirations of the middleclasses. As party leaders they both shared a similar desire to centralise policy making and attempted to promote the idea that radicalism could be achieved from a political position that transcended the left-right divide. 
Indeed Owen was warm in his approval of the early Blair period, a time when the party's policies were closest to those of the Owenite SDP. During Blair's first term he was comfortable suggesting that the SDP was the original architect of many New Labour policies. ${ }^{89}$ However, the comparison can certainly be taken too far when we consider the post-2001 trajectory of New Labour which has, in some respects, seemed to travel beyond Owen's synthesis in a drift towards the centre. The SDP's 'Basic Benefit' scheme (largely an Owen-driven initiative) may have been selective in nature, but it still maintained social justice as its primary goal, whereas Blair's priorities at times lent towards economic productivity. ${ }^{90}$ In short, while large chunks of Owen's thought were compatible with social democratic goals, New Labour's social democratic record, particularly in its later period, had much more to do with achievements rather than ideological aspirations. Indeed in 2009 Owen remarked that he was 'to the left of the majority of New Labour people' and complained that Labour was insufficiently social democratic. ${ }^{91}$

Nonetheless, even if caution should be exercised when drawing comparisons between Owen and Blair, we can safely assert that they experienced a shared ideological trajectory. The similarities of their respective journeys perhaps reflect the difficulty that late twentieth-century social democrats have faced when trying to place their ideological commitments within a workable and electorally attractive programme. ${ }^{92}$ In their efforts to improve their appeal, both Owen and Blair felt the need to emphasis their break with the policies and language of the social democratic tradition, even if they departed from it in slightly different ways.

\section{Conclusion}

Rooted in his particular accommodation with Rawlsian ideas, David Owen's revisionism distanced him from the more full-blooded social democracy that had been upheld by previous generations of left intellectuals. A better understanding of Owenism can shed new light on our understanding of social democractic fortunes in the late twentieth-century. The fact that Owen's populism seemed to be in conflict with a radical conception of social democracy, and that a similar revisionist project proved to be electorally successful in the 1990s, perhaps suggests that a cautious approach should be taken when attempting to repair the declinist historiography of 1980s social democracy. It may appear that Owen was facing the future when he attempted to create a new template for British social democracy, but it was a template that offered ideological retreat as well as electoral advance.

NOTES

\footnotetext{
${ }^{1}$ The author would like to thank Martin Farr, Jeremy Nuttall and Hugh Pemberton for their comments on earlier drafts of this article.
} 
${ }^{2}$ D. Owen, Time To Declare, Penguin, 1992. The book has recently been updated and re-issued: D. Owen, Time To Declare: Second Innings, Methuen, 2009.

${ }^{3}$ M. Beech,, 'David Owen' in M. Beech and K. Hickson, Labour's Thinkers, 2007, pp. 196-219. Tudor Jones, 'The SDP's Ideological Legacy' Journal of Liberal Democratic History, 18, 1998. Matthew Lakin, 'David Owen, New Labour and the Social Market Economy' Masters dissertation published online by the Social Market Foundation: http://www.smf.co.uk/assets/files/Dissertation_Lakin.pdf. D. Brack, 'David Owen and the Social Market Economy' Political Quarterly, 64:4, pp. 463-476.

${ }^{4}$ Tudor Jones, SDP, p. 7. Brack, 'Owen and the Social Market', pp. 472-476

${ }^{5}$ D. Brack, 'David Owen and the Social Market' Journal of Liberal History, 47, p. 58.

${ }^{6}$ Lakin, 'David Owen' p. 42.

${ }^{7}$ R. Desai, Intellectuals and Socialism, Lawrence \& Wishart, 1994, p. 183.

${ }^{8}$ W. Kennet (ed.) The Re-Birth of Britain, SDP, 1981. I. Bradley, 'Unravelling exactly what the SDP stands for' The Times, 4 August 1981.

${ }^{9}$ I. Bing to A. Kilmarnock, 29 July 1984. Tawney Society Archive, University of Essex, papers of the Political Philosophy Forum. Jeremy Josephs, Inside The Alliance, John Martin, 1983.

${ }^{10}$ D. Sainsbury, speaking at a witness seminar, 25 January 1991, 'The Launch of the SDP, 1979-1981' Twentieth Century British History, 7, 1993, p. 437.

${ }^{11}$ W. Rodgers, Fourth Amongst Equals, Politicos, 2000, p. 208.

${ }^{12}$ Owen, Personally Speaking, p. 26.

${ }^{13}$ D. Owen, D. Marquand and J. Mackintosh, Change Gear: Towards a Socialist Strategy, Socialist Commentary, 1967. Owen, Personally Speaking, p. 41.

${ }^{14}$ Owen, Time To Declare, p. 130.

${ }^{15}$ Owen, Time To Declare, pp. 438-480.

16 'Dr Owen in call for Labour to spurn the left' The Times, 1 August 1980.

${ }^{17}$ David Owen, Face The Future, Jonathan Cape, 1981, inside cover.

${ }^{18}$ P. Whitehead, 'Born Again' London Review of Books, 19 February 1981.

${ }^{19}$ I. Bradley 'Unravelling exactly what the SDP stands for' The Times, 4 August 1981.

${ }^{20}$ D. Owen, Face The Future, Jonathan Cape, 1981.

${ }^{21}$ D. Owen, Time To Declare, p. 166, p. 207.

${ }^{22}$ Owen, Face The Future, p. 172.

${ }^{23}$ Owen, Time To Declare, p. 599.

${ }^{24}$ Owen, Time To Declare, p. 598.

${ }^{25}$ Owen, Time To Declare, p. 94.

${ }^{26}$ Minutes of an exchange between David Marquand and Michael Meadowcroft: Liberalism and Social Democracy, Liberal Publication Dept., December 1980.

${ }^{27}$ R. Samuel, 'Mrs Thatcher's Return to Victorian Values' in T.C Smout (ed.) Victorian Values (Oxford: OUP, 1992) pp. 9-29.

${ }^{28}$ Owen, Time To Declare, p. 208.

${ }^{29}$ D. Owen, 'The Politics of Prosperity and the Politics of Poverty' Salford University, 12 September 1981.

${ }^{30}$ For journalist Ian Bradley it was this that meant Owen was still firmly within the socialist tradition:

I. Bradley, 'Rushing Out the Owen Manifesto' The Times, 29 January 1981.

${ }^{31}$ Owen, A Future That Will Work, p. 108.

${ }^{32}$ Ibid.

${ }^{33}$ A. Crosland, Socialism Now and other essays, London, 1974. R. Plant, 'Social Democracy' in D. Marquand and A Seldon (eds.) The Ideas That Shaped Post-War Britain, New Statesman, 1996, p. 170.

${ }^{34}$ A. Crosland, The Future of Socialism, Constable, 2006, p. 87.

${ }^{35}$ Cited in R. Hattersley, 'To imagine Labour's future, rewind 50 years' The Times, 15 September 2006.

${ }^{36}$ I. Bing and K. Carey 'John Rawls and American Liberalism' in A. Kilmarnock (ed.) The Radical Challenge, Andre Deutsch, 1987.

${ }^{37}$ Owen, A Future That Will Work, pp. 104-131.

${ }^{38}$ Owen, A Future That Will Work, p. 131.

${ }^{39}$ Owen, A Future That Will Work, p. 28.

${ }^{40}$ B. Crick, Socialist Values in Time, Fabian Society, 1984, p. 14.

${ }^{41}$ R. Behrens, 'Social Democracy and Lliberalism' in L. Tivey and A. Wright, Party Ideology in Britain, London, 1989, p. 90.

${ }^{42}$ Owen, A Future That Will Work, p. 109. 
${ }^{43}$ Owen, A Future That Will Work, p. 108. This remark caused some controversy among Liberals who accused Owen of imitating the arguments of Conservative 'wets'. 'Liberals accuse Owen of wooing Tory wets' The Times, 20 March 1984.

44 The 'social' component of the market had only weak impulses towards protecting industries that could lose out to open markets. See Owen, A Future That Will Work, p. 20-22.

Owen, A Future That Will Work, p. 104.

45 Tony Crosland's widow, Susan, wrote an emotional letter to The Times arguing that her husband would have deplored defection and that he had suggested before his death that some of those involved 'had moved so far to the right that they've disappeared from sight'. The Times, 19 January 1981.

${ }^{46}$ Owen, Face The Future, p. 119

47 Williams' 1981 book Politics Is For People objected to the free market fiercely: 'The Market is geared to individual demands and to individual purses; in meeting them, it does not count social costs.'

S. Williams, Politics Is For People, Penguin, 1981, pp. 46-47.

${ }^{48}$ R. Plant, Equality, Markets and the State, Fabian Society, London, 1984, p. 12.

${ }^{49}$ Owen, A Future That Will Work, p. 20-22.

Owen, A Future That Will Work, p. 104.

${ }^{50}$ D.Owen, speech to the Council for Social Democracy, 12 September 1980. Owen, Time To Declare, p. 801.

${ }^{51}$ Marquand, The Progressive Dilemma, p. 204.

${ }^{52}$ Plant, Equality, Markets and the State, p. 1.

53 'The good doctor' The Economist, 1 September 1984.

${ }^{54}$ Owen, Time To Declare, p. 766.

${ }^{55}$ S. Mennell, On Social Democratic Ideology, Tawney Society, London, 1983.

${ }^{56}$ Crosland, Future of Socialism, p. 345.

${ }^{57}$ G.D.H Cole, 'Twentieth Century Socialism’ New Statesman, 7 July 1956.

${ }^{58}$ Owen, Time To Declare, p. 801.

${ }^{59}$ R. Jenkins, What Happens Now, London, Fontana, 1972, p. 29. Owen had some role in writing the speeches that formed this book. Owen, Time To Declare, p. 189.

${ }^{60}$ R. Jenkins, Partnership of Principle: Writings and Speeches on the Making of the Alliance, London, Secker \& Warburg, 1985.

${ }^{61}$ Cited by P. Sykes, Losing From The Inside: The Cost of Conflict in the British SDP, Transaction, 1988 , p. 99. Interestingly, Owen regarded Jenkins' economic views as being very similar to the 'Conservative paternalists'. Owen, Time To Declare, p. 497. He has also suggested that his disagreements with Jenkins' leadership of the SDP had nothing to do with him being more 'left-wing' than Jenkins. Time To Declare, p. 446.

${ }^{62}$ W. Rodgers, 'Biography: David Owen' in Journal of Liberal History, 39, Spring 2003, p. 44.

${ }^{63}$ Although the first membership list of the PPF included a hand-written notation, 'Owen interested', he did not join. He did welcome the work of the Tawney Society in a letter to Tony Flower, 20 May 1985. Tawney Society Archives, Boxes 23 and 33.

${ }^{64}$ Ibid., p. 134.

${ }^{65}$ Marquand, The Progressive Tradition, p. 170.

${ }^{66}$ J. Nuttall, 'Labour Revisionism and qualities of mind and character, 1931-1979' English Historical Review, Vol. 120, p. 670.

${ }^{67}$ Owen, 'The Enabling Society' pp. 235-264.

${ }^{68}$ J. Nuttall, 'Tony Crosland and the many falls and rises of social democracy' Twentieth Century British History, 18: 4, p. 59.

${ }^{69}$ Nuttall, 'Labour Revisionism’ p. 684.

${ }^{70}$ Cited by Nuttall, 'Labour Revisionism', p. 692.

${ }^{71} \mathrm{~K}$. Theakston and E. Gouse, 'Central and local government' in Anthony and Kevin Hickson (eds.), New Labour, Old Labour (London, 2004), p. 216.

72 Owen, Time To Declare, p. 41.

${ }^{73}$ Owen, Time To Declare, p. 599.

${ }^{74}$ Brack, 'David Owen and the Social Market Economy', pp. 468-476.

75 Owen, A Future That Will Work, p. 20. Owen, Our NHS

${ }^{76}$ Marquand, The Progressive Tradition, p. 204.

77 D. Owen, 'My Plan For Recovery', The Times, 28 August 1984. His 1986 book A United Kingdom was almost entirely focussed on the idea of reversing economic decline. 
${ }^{78}$ R. Holme, 'Fear and Loathing in Limehouse' London Review of Books, 3 Sept. 1987. Tim ClementJones 'One Man's Pride: Owen and his impact on the Alliance' Journal of Liberal Democratic History, Vol. 18 (1998).

${ }^{79}$ Marquand, Progressive Dilemma, p. 201.

${ }^{80}$ Marquand, Progressive Dilemma, p. 204.

${ }^{81}$ R. Holme, 'Fear and Loathing in Limehouse' London Review of Books, 3 Sept. 1987.

${ }^{82}$ Beech, 'David Owen’ p. 211.

${ }^{83}$ Interview with James Naughtie, BBC Radio 4's Today programme.

${ }^{84}$ P. Mandelson and R.Liddle, The Blair Revolution, London, 1996, p. 29.

${ }^{85}$ Blair's autobiography makes only a passing mention of Owen and the SDP: Tony Blair, A Journey, Hutchinson, 2010, p. 89. It is also worth noting the fragmented nature of New Labour as an intellectual project. See Michael Freeden, 'The Ideology of New Labour' The Political Quarterly, 70:1, p. 43.

${ }^{86}$ Noel Thompson, Political Economy and the Labour Party, London, 2006, pp. 250-256.

${ }^{87}$ N. Thompson, Political Economy, pp. 267-286.

${ }^{88} \mathrm{~A}$ comparison of their separate accounts of these events is illuminating: Owen, Time To Declare, $\mathrm{p}$. 629-632; T. Blair, A Journey, Hutchinson, 2010, pp. 83-87.

89 'Owen's praise for Labour' BBC News, 13 May 1999.

http://news.bbc.co.uk/1/hi/uk_politics/342629.stm; 'SDP “thought of new Labour first', BBC News, 29 August 2000. http://news.bbc.co.uk/1/hi/uk_politics/900903.stm.

${ }^{90}$ Owen, A Future That Will Work, pp. 109-110.

91 The Festival of Politics, Edinburgh, 22 August 2009.

92 Michael Stewart's review of Roy Hattersley's 1987 work Choose Freedom explored the new pressures upon left thinkers that had emerged since 1956: M. Stewart, 'Hattersley's Specifics' London Review of Books, 19 March 1987. 